\title{
Frame Head Production Process In Category 3 Frame Chassis At Pt. Prime Dual Core
}

\author{
${ }^{* 1}$ Abdul Muchlis, ${ }^{2}$ Sandy Suryady, ${ }^{3}$ Eko Aprianto Nugroho \\ ${ }^{1,2,3}$ Faculty of Industrial Engineering, Gunadarma University \\ * Corresponding author: \\ Email: muchlis07@staff.gunadarma.ac.id
}

\begin{abstract}
.
The frame is the main component of the chassis that functions to withstand shock, pressure and vibration when operating on the road. The chassis frame is made of SS400 material which has a good level of strength to withstand static loads, the Frame Chassis formation process uses a cold working process. This writing aims to determine the production process of the Frame Head on the Frame Chassis category 3 as well as knowing the machines used in the Frame Head production process and knowing the total tonnage required for the 400 ton Stamping machine in the blanking and piercing process on the Crossmember 0101 part, from observations that have been made. it was done that to carry out the Frame Head production process on Frame Chassis category 3, through the process of forming material or forming with the blanking, piercing, and bending methods using a 300 ton to 500 ton stamping machine, then continued with the unification process using a GMAW welding machine ( Gas Metal Arc Welding), then continued with the painting process using powder coating with the dipping method for 2 minutes, and in the Crossmember 0101 forming part process using a 400 ton Stamping machine, the total tonnage of the blanking and piercing cutting force was obtained on the Crossmember 0101 part (added with backup/strippin style $\mathrm{g}$ force) is 470.069 Tons.
\end{abstract}

Keywords: Frame Chasis, Truck Fuso

\section{INTRODUCTION}

The need for transportation facilities is growing very rapidly in Indonesia. The need for commercial vehicles, especially trucks, shows the same trend. A truck is a means of transportation that is used as the distribution of goods such as basic necessities, clothing, and automotive equipment. Trucks have a heavy duty as a distribution tool, so the role of the Frame Chassis is very important.The frame is the main component of the chassis where other components of the chassis are assembled and connected. Frame construction material used must be rigid and strong so that the Frame can withstand shock, pressure and vibration when operating on the road. Frame Chassis formation process using the Cold Working process.In the Frame Chassis manufacturing industry generally prefer to use the Forming method for the formation of plate sheets using a Stamping machine with the help of Dies.Frame Chassis category 3 is a type of Frame Chassis that is often used in Fuso truck types. In the Frame Chassis category 3 there are several parts, such as Siderell and some Crossmembers. Crossmember is a Frame Chassis component that functions to assemble the two Siderells into a complete Frame Chassis. Crossmember 0201, also known as the Frame Head, functions as a truck light holder.In connection with this, the authors are interested in writing about the production process of Frame Head on Frame Chassis category 3.

\section{LITERATURE REVIEW Definition of Frame Head}

The frame is the main component of the chassis where the other components of the chassis are assembled and connected. Frame construction material used must be rigid and strong so that the Frame can withstand shocks, bends, pressure and vibration when operating on the road. The following are some of the main functions of the Frame Chassis: [1]

1. To carry all Stationary loads attached to the Chassis and the load of passengers and goods transported;

2. To withstand torsional vibrations caused by vehicle movement;

3. To withstand the centrifugal force that occurs when the vehicle is cornering; 
4. To control the vibrations that occur when the vehicle is operating;

5. To withstand the bending stress due to the rise and fall of the front and rear axles.

The Frame Head is a component of the Frame Chassis which functions as a holder for the lights on the category 3 fuso truck, the Frame Head is located at the front of the category 3 fuso truck.

The main discussion in this paper is the production process of the Frame Head Fuso truck category 3 and calculating the tonnage on Crossmember 0101.

\section{Materials}

In the process of making the Frame Head, it is very important to know the nature and structure of the material, to be considered in terms of strength and safety factors. In the process of making the Frame Head there is only 1 main type of material used. Which will be explained as follows:

\section{Cutting Steel Blank SS 400}

SS400 steel plate and other steel products are applied to the general structural construction of bridges and ships, the final products are always supplied Hot Rolled. Steel products made of SS400 carbon steel are very popular for proper tensile strength and toughness, good plasticity, welding performance and processing properties [2].

\section{Metal Cold Working Process}

Cold working process is the process of plastically forming metal with a working temperature below the recrystallization temperature. The types of cold working used in the Frame Head manufacturing process are as follows:

\section{a. Blanking}

Blanking process is the separation of metal with two blades that move continuously from top to bottom. In blanking, the metal in contact with the blade will undergo plastic deformation, until cracks propagate inward and a complete separation occurs [3]. Things to consider in the Blanking process are as follows:

1. Design Dies for Blanking process;

2. Design Punch for Blanking process;

3. type, thickness, dimension of the material to be indexed;

4. the power of the blow;

5. punch speed;

6. the condition of the knife edges of the Punch and the condition of the Dies;

7. Punch and Dies ingredients.

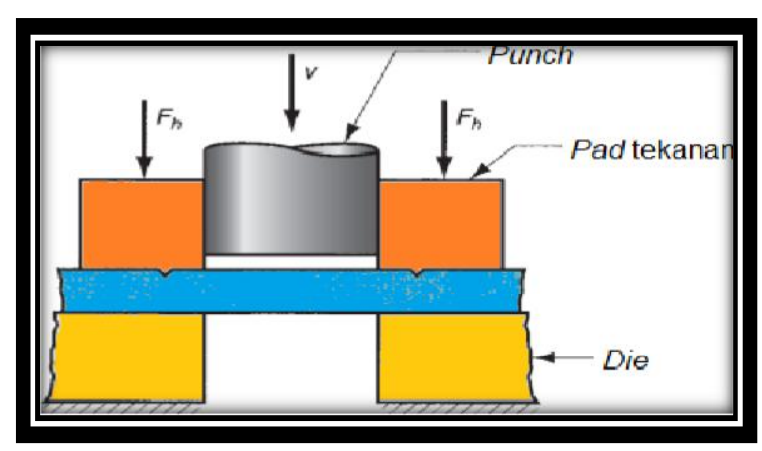

Fig 2.1. Blanking Process Scheme

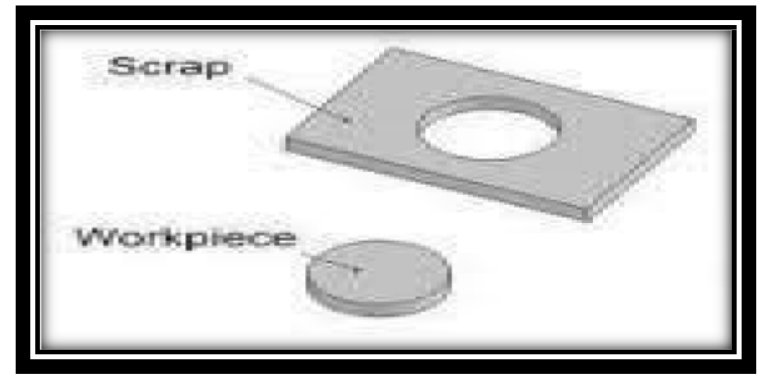

Fig 2.2. Example of Sheet Metal after Blanking Process. 


\section{b. Piercing}

Piercing is a sheet metal cutting process that produces holes in one stroke of pressing, on a flat or contoured surface. In the Piercing process, the resulting holes can be round or other shapes, depending on the shape of the punch used. In the Piercing process as well as the Trimming process. Trimming is a process of cutting waste material, in order to get this finishing it is used to cut the rest of the withdrawal [4]. Trimming process will remove parts that are not needed or scrap.

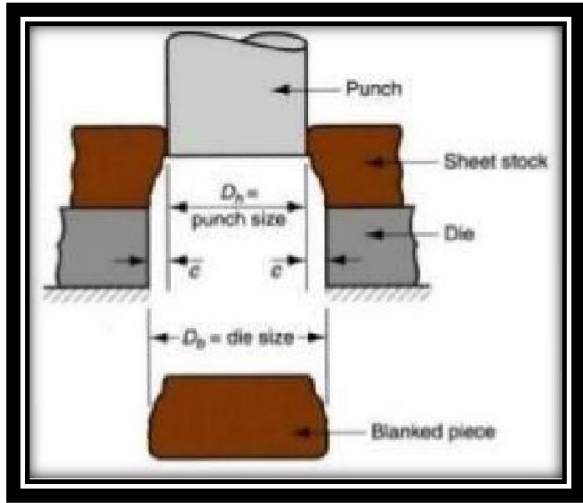

Fig 2.3. Schematic of the Piercing Process.

punch is a tool used to cut sheet metal into the desired shape, using dies or molds. Things to consider in the Piercing process are as follows:

1. punch power

2. punch speed

\section{Surface Condition}

4. Punch and Dies . ingredients

5. Condition of knife edges of Punch and condition of Dies

6. lubrication and number of clearances.

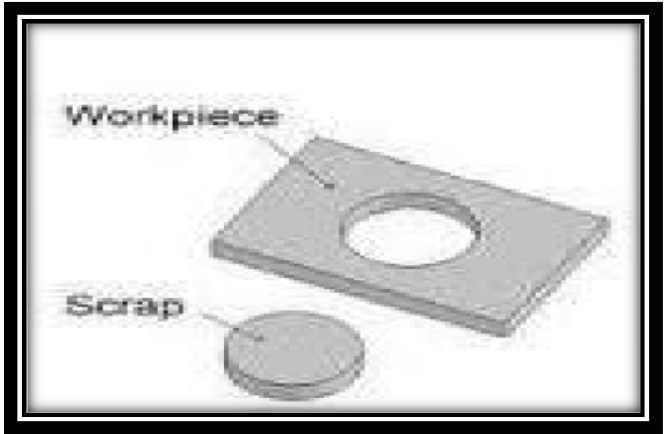

Fig 2.4. Example of Sheet Metal after Piercing Process.

\section{c. Bending}

Bending is a sheet metal forming process that produces indentations in one pressing step, on a flat surface. In the bending process, the resulting indentation varies depending on the Dies and Punch used.

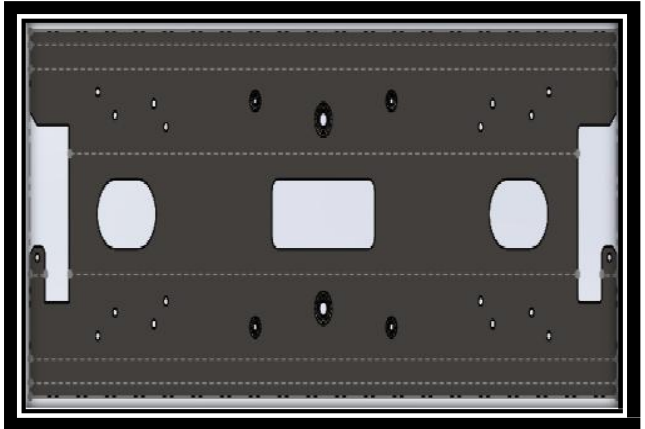

Fig 2.5. Example of Sheet Metal before Bending Process. 


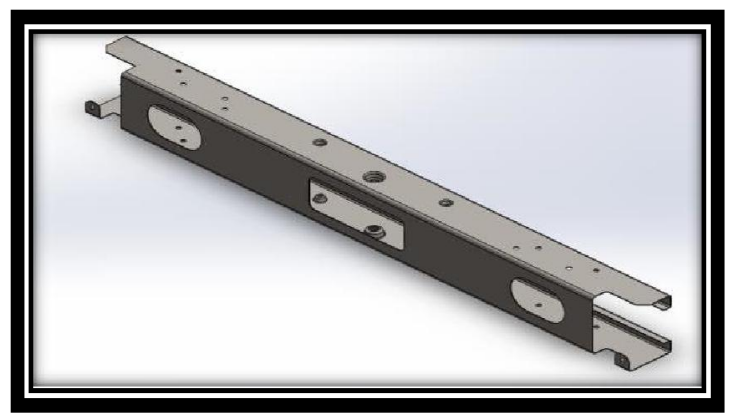

Fig 2.6. Example of Sheet Metal after Bending Process.

\section{Machines Used}

In the basic manufacturing process for the Frame Head using machine tools, these machines can be grouped into three main parts including:

1. Material forming machine.

2. Materials uniting machine.

3. Material painting machine.

\section{RESEARCH METHOD}

\section{Frame Head Making Process Flowchart}

In the process of making this Frame Head there are several stages of the process that need to be done including:
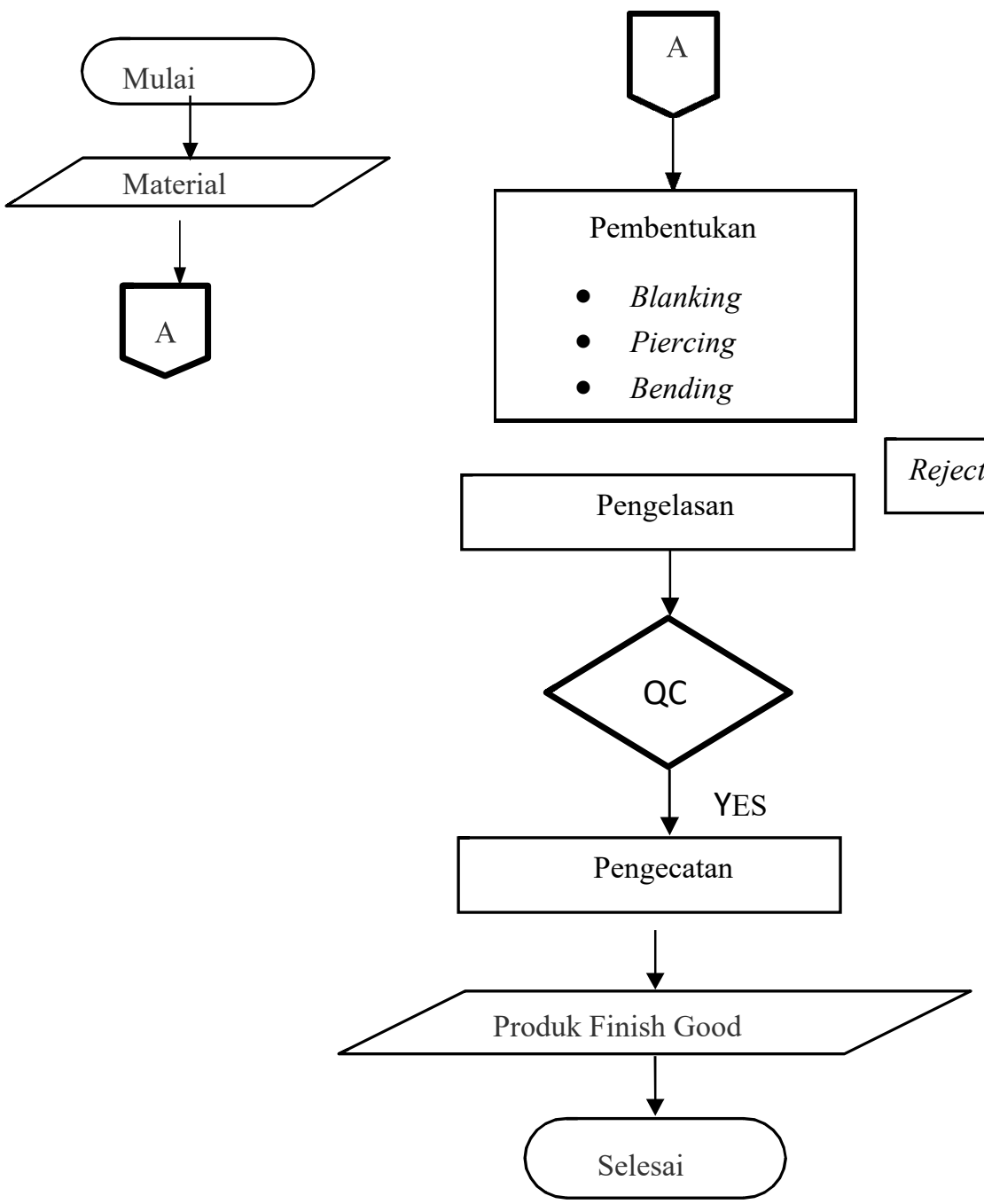


\section{RESULTS AND DISCUSSIONS \\ Material}

The material used for the Fream Head manufacturing process is the main material, namely Carbon Steel ASTM A36 Steel / SS 400. SS400 steel plate as Carbon and low alloy steel. SS400 is used because this material is capable of bending but still has a good level of strength to withstand static loads. The following are the parts contained in the Fream Head and the materials used for the process of making the Fream Head, as follows:

Material Fream Head

\begin{tabular}{|c|l|l|c|}
\hline NO & \multicolumn{1}{|c|}{ NAMA PART } & MATERIAL & DIMENSI (mm) \\
\hline 1 & Crossmember 0201 & $\begin{array}{l}5,0 \times 630 \times 1940 \\
\mathrm{~mm}\end{array}$ \\
\hline 2 & Reinforcemen Lower & Cutting Steel Blank SS400 & $5,0 \times 436 \times 500 \mathrm{~mm}$ \\
\hline 3 & $\begin{array}{l}\text { Bracket Assy 1309 \& } \\
1409\end{array}$ & Cutting Steel Blank SS400 & $2,5 \times 170 \times 172 \mathrm{~mm}$ \\
\hline 4 & Crossmember 0101 & Cutting Steel Blank SS400 & $2,5 \times 106 \times 900 \mathrm{~mm}$ \\
\hline
\end{tabular}

\section{Chemical elements Steel Blank SS400}

\begin{tabular}{|c|c|c|c|c|c|}
\hline $\mathrm{C}$ & $\mathrm{Si}$ & $\mathrm{Mn}$ & $\mathrm{P}$ & $\mathrm{S}$ & $\mathrm{Cr}$ \\
\hline $0.19-0.21$ & $0.05-0.17$ & $0.4-0.6$ & 0.04 & 0.05 & $\leq 0.3$ \\
\hline
\end{tabular}

\section{Mechanical Properties SS400}

\begin{tabular}{|c|c|c|c|c|c|c|c|c|}
\hline \multirow{2}{*}{ Material } & \multicolumn{4}{|c|}{ Elongation \% } & \multicolumn{4}{c|}{ Tenslee Strength (Mpa) } \\
\cline { 2 - 9 } & $\begin{array}{c}\text { Thickn } \\
\text { ess } \\
2,5 \mathrm{~mm}\end{array}$ & $\begin{array}{c}\text { Thickn } \\
\text { ess } \\
3,2 \mathrm{~mm}\end{array}$ & $\begin{array}{c}\text { Thickn } \\
\text { ess } \\
3,0 \mathrm{~mm}\end{array}$ & $\begin{array}{c}\text { Thickn } \\
\text { ess } \\
4,0 \mathrm{~mm}\end{array}$ & $\begin{array}{c}\text { Thickn } \\
\text { ess } \\
2,5 \mathrm{~mm}\end{array}$ & $\begin{array}{c}\text { Thickn } \\
\text { ess } \\
3,2 \mathrm{~mm}\end{array}$ & $\begin{array}{c}\text { Thickn } \\
\text { ess } \\
3,0 \mathrm{~mm}\end{array}$ & $\begin{array}{c}\text { Thickn } \\
\text { ess } \\
4,0 \mathrm{~mm}\end{array}$ \\
\hline $\begin{array}{c}\text { SPH } \\
440\end{array}$ & $36 \mathrm{~min}$ & $29 \mathrm{~min}$ & $25 \mathrm{~min}$ & $31 \mathrm{~min}$ & $485 / 480$ & $496 / 493$ & $486 / 491$ & $500 / 502$ \\
\hline
\end{tabular}

In table 3.1 there are four components of the Frame Head along with the materials used in the manufacture of the Frame Head. The material used in the manufacture of the Frame Head is only one type of material, namely SS 400. In table 3.2 explained about the chemical elements contained in SS400. Table 3.3 also describes the Mechanical Properties of SS400.

\section{Formation of Crossmember 0201}

In Crossmember 0201 the main material is Cutting Steel Blank SS 400 which has a size of $5.0 \times 630$ x $1940 \mathrm{~mm}$, Crossmember 0201 is formed using a mold called Dies. In the process of forming Crossmember 0201, it goes through several processes, namely the Blanking, Piercing, and Bending processes.

\section{Formation of Reinforcement Lower}

In Reinforcement Lower the main material is Cutting Steel Blank SS 400 which has a size of $5.0 \mathrm{x}$ 436 x $500 \mathrm{~mm}$, Reinforcement Lower is formed using a mold called Dies. In the process of forming the Lower Reinforcement through several processes, namely the Blanking, Piercing, and Bending processes.

\section{Formation of Bracket Assy 1309 \& 1409}

In Bracket Assy 1309 \& 1409 the main material is Cutting Steel Blank SS 400 which has a size of $3.2 \times 135 \times 405 \mathrm{~mm}$, Bracket Assy $1309 \& 1409$ are formed using a mold called Dies. In the process of forming Bracket Assy 1309 \& 1409, it goes through several processes, namely the Blanking, Piercing, and Bending processes.

\section{Formation of Crossmember 0101}

In Crossmember 0101 the main material is Cutting Steel Blank SS 400 which has a size of $2.5 \times 106$ x $908 \mathrm{~mm}$, Crossmember 0101 is formed using a mold called Dies. In the process of forming Crossmember 0101, it goes through several processes, namely the Blanking, Piercing, and Bending processes. 


\section{Welding}

The next step in the process of making the Frame Head is welding or welding. This line is called the Deimler Welding process, where this welding process combines all components that have gone through the Stamping process. This process uses a GMAW (Gas Metal .) welding machine Arc Welding) which welding itself uses shielding gas (Shielding Gas) so as not to be contaminated with free air which can cause porosity defects in the weld joint, and uses a coil of wire as the connecting material, which comes out along with the protective gas at the nozzle. The type of gas used is carbon dioxide gas $(\mathrm{CO} 2)$ because this gas has excellent oxidizing properties.

\section{Welding Deimler Op 4}

The beginning of the welding process occurs in OP 4, Crossmember 0201 which has gone through the Bending process is placed on the pallet to be then sent to the Welding Deimler process, from the pallet it is moved to JIG OP 4 then the operator takes M10 size bolts from the box under JIG OP 4 and then puts it in the Crossmember hole 0201 then clamped using clamps and then welding in a circle on the side of the bolt. After welding, then move it to OP 5 by using a crane.

\section{Welding Deimler Op 5 and Op 3}

The next process is OP 5 and OP3, in this OP OP 3 acts as support for OP 5, the Crossmember 0201 part of OP 4 is placed on the JIG OP 5 then the operator takes the M10 bolt in the box then installs it in the holes on the right and left of Crossmember 0201 and tightens using clamps and then welding in a circle.

\section{Welding Deimler Op6 and Op2}

Next is the OP6 and OP2 processes, in this OP OP2 acts as support for OP6, the 0201 Crossmember part of OP5 is placed on the OP6 JIG. Then the operator switched to OP2, in OP2 the operator took and placed Crossmember 0101 in JIG OP2 and installed M10 nut on six holes in Crossmember 0101 then locked by JIG OP6 and welded in a circle.

\section{Welding Deimler Op7 and Op1}

In the OP7 and OP1 processes, OP1 acts as support for OP7, Crossmember part 0201 of OP6 is placed on the OP7 JIG. Then the operator moves to OP1, on OP1 the operator takes and places the Bracket Assy 1309 \& 1409 on the JIG OP1 then installs the M10 nut then locks the JIG OP1 and then welding by means of circular welding and welding the inside.

\section{QC (Quality Control)}

Quality Control is the inspection process of the product produced by the operator. Checks are carried out visually and using a Dermatograph, in this Quality Control process the operator will check in detail each item the parts that have been welded, are there any defective or missed welding parts in the Deimler Welding process. If there is a defect or missing part of the welding in the resulting product, the operator will immediately repair the product, the defect here is in the sense of a minor defect. Repair by grinding the defective part with the aim of eroding the defective part of the welding so that it can be re-welded and for parts of the product that have been missed, the missing part will be welded. If the resulting defect is severe enough, the product will be separated for further inclusion in the NG (Not Good) category or also called reject product which will later be recycled.

\section{CONSLUSION}

Based on the results of practical work carried out in the Frame Head production process, there are several things that we can conclude from scientific writing, including the following:

1. The Frame Head production process starts from taking Cutting Steel Blank SS 400 material. Next is entering the Forming process, in this Forming process there are three methods, namely the Blanking, Piercing, and Bending processes using a stamping machine with a capacity of 300 Tons to 500 Tons, then proceed with the process of unifying the material using a GMAW (Gas Metal Arc Welding) welding machine which is done manually. After the Welding process is carried out, QC (Quality Control) is carried out using Dermatography to avoid whether there are parts that are missed by welding or porosity, if there is porosity, the operator makes repairs by patching it. After the process of unifying the Frame Head product material enters the painting process, the painting process uses powder coating or commonly called powder 
coating with the dip method for 2 minutes. Next is the product checking process (Quality Control). Product checks are carried out to avoid defects and ensure perfect final conditions, before being assembled into Category 3 Frame Chassis.

2. The machines used for the Frame Head production process are the Forming process using the Aida brand Stamping machine with a tonnage of 300 tons to 500 tons, for the material union process using a GMAW (Gas Metal Arc Welding) welding machine, and for the painting process using the conveyor with the immersion method for 2 minutes.

3. In the Forming process of Crossmember 0101 using a Stamping machine of 400 tons, the results of the calculation of the tonnage required for the Blanking and Piercing process on the Crossmember 0101 part (plus the backup force / stripping force) is 470.069 Tons.

\section{SUGGESTIONS}

Based on the results of practical work carried out in the Frame Head production process, there are suggestions and input from the authors, including the following:

1. The author suggests that interns / practical work may then be able to discuss about jig aids in the welding process. This is done in order to be able to complete additional information regarding the tools used in detail.

2. The author suggests that for interns / practical work, it is possible to conduct a discussion about the analysis of dies on the stamping machine.

\section{REFERENCES}

[1] Abubakar, M., Krisnowo, A., Suryaputra, H., \& Noviantoro, B. (2017). Design dan Analisis Statik Rangka Chassis Square Bar dengan FEM. Mesin, 26(2), 102-111.

[2] China Brill Special Steel. SPH440 OD Specification of Material.

[3] Faisyal, Y. (2002). Perencanaan Proses Produksi Packing Silinder Head Honda GL 200 Dengan Proses Blanking.

[4] Susanto, S. (2017). Modifikasi Profressive Tool Plat Penyangga Baut Gear Belakang Pada Sepeda Motor Yamaha Jupiter Kapasitas 300 Buah/Jam. Jurnal Teknik Mesin, 7(02).

[5] Ardhayananta, Hosta. dkk. Pengaruh Pengerjaan Dingin Terhadap Ketahanan Korosi Lapisan Hasil Hot Dip Galvanizing AISI 1020 di Media NaCl. Surabaya: Institut Teknologi Sepuluh Nopember Surabaya.

[6] Eriko, S. (2014). Modifikasi Dies Dengan Variasi Radius Fillet Untuk Meminimalisir Die Fill Defect Pada Produk Metal Gasket (Doctoral dissertation, Universitas Brawijaya).

[7] Saputra Utama, R. I. Z. K. I. (2019). Modifikasi Las GTAW Semi Otomatis Dengan Penambahan Feeder Las GMAW (Doctoral dissertation, Vokasi undip).

[8] Miranda, Y., \& Made, A. M. (2020). Analisa Perbedaan Temperatur Pada Material Baja Karbon Rendah S355JO Terhadap Distorsi Pada Pengelasan SMAW. Zona Mesin: Program Studi Teknik Mesin Universitas Batam, 9(1).

[9] Novianto, N. D. (2015). Penggunaan Alat Pelindung Diri (APD) Pada Pekerja Pengecoran Logam PT. Sinar Semesta (Studi Kasus Tentang Perilaku Penggunaan Alat Pelindung Diri (APD) Ditinjau Dari Pengetahuan Terhadap Potensi Bahaya Dan Resiko Kecelakaan Kerja Pada Pekerja Pengecoran L. Jurnal Kesehatan Masyarakat (e-Journal), 3(1), 417-428.

[10] Nastiti, H. (2014). Analisis Pengendalian Kualitas Produk Dengan Metode Statistical Quality Control (Studi Kasus: pada PT “X” Depok). Sustainable Competitive Advantage (SCA), 4(1). 